\title{
Determining Levels of 8th Grade Students of Secondary School to Understand Cognitive Structures and Concepts Concerning Concepts of Fundamental Citizenship
}

\author{
Gökçe Kılıçoğlu \\ Correspondence: Gökçe Kılıçoğlu, Gazi University, Gazi Faculty of Education, Department of Turkish and Social \\ Sciences Education, Ankara, Turkey.
}

Received: August 1, 2018

doi:10.11114/jets.v6i11.3505
Accepted: September 20, 2018 Online Published: September 25, 2018

URL: https://doi.org/10.11114/jets.v6i11.3505

\begin{abstract}
Purpose of this study is to determine cognitive structures, conceptual knowledge and misconceptions of the $8^{\text {th }}$ grade students concerning concepts of citizenship through a word association test. In direction of this purpose, a word association test consisting of democracy, sovereignty, independency, freedom, right and responsibility concepts have been applied to $1758^{\text {th }}$ grade students who studied at 3 secondary schools in Trabzon province during 2017-2018 school years. Conceptual networks have been formed in direction of responses of the students to these concepts, and cognitive structures of the students have been demonstrated. It has been concluded as a result of the study that students associate concept of democracy mostly with equality, right, justice concepts. They associate concept of sovereignty with freedom, nation, independence concepts and concept of independency with freedom, flag and liberty concepts. They also associate concept of freedom with independency, justice, liberty concepts and concept of right with freedom, nation and sovereignty concepts. They associate again concept of responsibility with task, duty and work concepts. It has been determined as a result of the study that a good part of the students can make sentences involving scientific information about freedom, independency and responsibility concepts and they have no misconceptions about these concepts. It has been determined that a limited number of students have misconceptions about the concept of right. As for one of the important results of the study, most of the students have misconceptions about the concept of sovereignty.
\end{abstract}

Keywords: citizenship, social studies, word association test

Purpose of this study is to determine cognitive structures and misconceptions of the $8^{\text {th }}$ grade students concerning democracy, sovereignty, independency, freedom, rights and responsibility concepts through Word Association Test (WAT) that is an alternative assessment and evaluation technique.

\section{Introduction}

Social Studies is a field of study arranged with an interdisciplinary approach which reflects subjects of social sciences and citizenship knowledge such as history, geography, sociology, psychology, anthropology, philosophy (MEB, 2005, p.46) in order that individual can actualize his existence in the society and so that individuals can be raised as a good and responsible citizen.

Citizenship consists of relationships between the state and individual. These relationships bring about naturally rights and responsibilities. These rights and responsibilities can be described as voting power, equality under the law, obeying the rules, participation in the elections, etc. (Doğanay, 2005, p. 19). In our country, characteristics of an effective citizen are as the following: to be a citizen who believe in democracy and set his heart on democracy, who has the citizen consciousness, who analyzes importance of his country and devotes his life to protect the country from any danger, who is deeply loyal to Atatürk's principles and who has had the responsibility to develop and enhance these principles, who makes it a philosophy of life to practice the constitution and its basic principles regarding his rights, responsibility, freedom and duties, who has had sense of keeping the Republic of Turkey alive that is a secular, democratic and social state and who has the title of patriotism (Safran, 2011, p. 7).

While effective citizenship is the general purpose of education system in a country, this duty is involved mostly in social studies class within the school programs (Doğanay, 2005, p. 19). Purpose of the citizenship education included within the scope of social studies education program is to ensure active participation of the students in country's rule and social 
life by informing them on their rights and responsibilities in the society where they live in, management and structure of the country and national security (Y1lmaz, 2003) and raise them as a citizen or individual and also contribute to development of democratic-politic period (Doğanay, 2005, p. 25).

Concepts are one of the basic elements of Social Studies Education Program. Students are informed in certain phases on the concepts belonging to not only social studies but also other disciplines constituting the social studies from $4^{\text {th }}$ grade to $7^{\text {th }}$ grade. These phases are introduction, development and consolidation. Knowledge of the students on cognitive structures formed in their intellectual structures concerning to the concepts is one of the most important indicators is to see to what extent students have known about the concepts. In terms of learning the concepts properly, it is important to teach the concepts to the students and assess whether they have learned these concepts or not. Possible misconceptions of the students couldn't be determined if concepts were taught incorrectly and any evaluation wasn't made, and it thus affect future learning of the students adversely. Word association tests are one of the assessment and evaluation techniques which enable to determine cognitive structures of the students about the concepts, whether they have learned the concepts correctly or not, and also their misconceptions.

Word association tests (WAT) is an alternative assessment and evaluation technique which enables to observe cognitive structures of the students, connection between the concept creating this structure and information network established in the mind and to determine whether the connection between the concepts has been established in long-term memory or not or whether the connection established is significant or not (Bahar, Johnstone and Sutcliffe, 1999; Bahar and Özatll, 2003: p.75; Özatlı and Bahar, 2010: p. 10).

When examining the literature, it is seen that there are a limited number of researches to demonstrate cognitive structures of the students concerning concepts of the citizenship. The studies were carried out mostly to determine levels of secondary school students to comprehend and understand concepts of the citizenship (Kaldırım, 2005, Kuş, 2012, Sadık and Sar1, 2012, Yılmaz, 2013, Kartal and Turan, 2015, Pala, 2018). As for the studies which determine cognitive structures of the students concerning the concepts of citizenship, they are in a limited number (Karatekin and Elvan, 2016). This study has been prepared to demonstrate cognitive structures of the students concerning the concepts of basic citizenship and determine their perceptions on these concepts and their understanding of the concepts. It is expected that the study designed for this purpose would contribute to the literature of social studies in conceptual sense.

\section{Method}

\subsection{Purpose of the Study}

Purpose of this study is to determine cognitive structures and misconceptions of the $8^{\text {th }}$ grade students regarding democracy, sovereignty, independency, freedom, rights and responsibility concepts through Word Association Test (WAT) that is an alternative assessment and evaluation technique.

\subsection{Study Model}

This study carried out to determine cognitive structures and misconceptions of $8^{\text {th }}$ grade students regarding concepts of democracy, sovereignty, independency, freedom, right and responsibility has been carried out in survey model. Word association test has been used to determine cognitive structures and misconceptions of the students concerning the concepts in question.

\subsection{Study Group}

Study group of the research consists of $1758^{\text {th }}$ grade students who studied at two Primary schools in Ankara province. 92 of them are female and 83 of them are male.

\subsection{Data Collection Tool}

In the study, word association test has been used as data collection tool to demonstrate cognitive structures and misconceptions of the students concerning the concepts in question. Responses given to word association tests are the techniques used in order to demonstrate cognitive structures of the students and the relation between the concepts creating this structure and to determine whether relationships between the concepts brought by the long-term memory are significant or not (Bahar, Johnstone and Sutcliffe, 1999). In addition, word association tests are used to determine misconceptions by examining relationships between the concepts (Çepni, Özmen ve Bakırcı, 2012, Bolat, Aydoğdu and Sağır, 2014).

In the study, concepts concerning the citizenship mentioned in social sciences lesson (democracy, sovereignty, rights, freedom, equality and responsibility) in order to create a word association test. The concepts chosen are prepared and presented to the students as seen in the following. 
Democracy.

Democracy.

Democracy.

Democracy.

Democracy.

The relevant sentence

Every key concept involved in data collection tool has been arranged to be involved in one page and students have been informed on necessary explanations both in instructions section and verbally. Besides, students were presented an example in instructions section. The students were allowed for one minute for every key concept. In this period, students were asked to write five response concepts and also the relevant sentences for every key concept.

\subsection{Data Analysis}

As a result of the study, response concepts concerning the key concepts have been analyzed in detail and a table has been prepared to demonstrate prevalence of these concepts. Breakpoints are determined by considering the frequencies. These specified breakpoints were practiced by breakpoint technique demonstrated by Bahar, Johnstone and Sutcliffe (1999). Then, conceptual networks have been created in direction of breakpoints. This technique can be explained shortly as follows: the most common word that is 3-5 lower than the given as answer to any key concept involved in word association test is determined as breakpoint. After that, breakpoint is decreased in certain intervals and this process continues until all key words appear at conceptual network. As a result of this process, concepts associated with key concepts involved in breakpoints specified at conceptual networks, and the relationships between these concepts are included. It was thus tried to demonstrate cognitive structures of the students. For example, response concepts given to the concepts for which breakpoint is specified at the interval 16 to 30 are given by the specified color. Response concepts for which breakpoint are specified at the interval 16 to 30 indicate that these concepts are repeated by the students at the interval 30 to 39. As for the relevant sentences involved in data collection tool, they have been analyzed by considering scientific definitions of the key concepts, and also response concepts. After this analysis, it has been tried to determine comprehension levels and misconceptions of the students on this concepts by means of the relevant sentences they wrote about the key concept. As a result of this analysis, sentences associated with the concept have been evaluated as sentences involving scientific information, sentences not involving scientific information, sentences involving misconceptions and empty sentences, and frequencies associated with the sentences evaluated according to these categories have been presented in tables. Then, sentences formed by the students about these categories have been exemplified.

\section{Findings and Comment}

Findings obtained by the study are presented using tables and figures. Frequencies of the words formed associated with the concepts of democracy, sovereignty, rights, freedom, equality and responsibility are illustrated in the following tables: 
Table 1. Frequencies of the words formed associated with key concepts

\begin{tabular}{|c|c|c|c|c|c|c|c|}
\hline & \multicolumn{7}{|c|}{$\begin{array}{r}\text { Key Concepts } \\
\end{array}$} \\
\hline & Democracy & Sovereignty & Independency & Freedom & Right & Responsibility & Total \\
\hline Responce Concepts & $\mathrm{n}$ & $\mathrm{n}$ & $\mathrm{n}$ & $\mathrm{n}$ & $\mathrm{n}$ & $\mathrm{n}$ & $\mathrm{n}$ \\
\hline Equality & 87 & 8 & 19 & 19 & 41 & - & 174 \\
\hline Right & 56 & 22 & 30 & 38 & - & 28 & 174 \\
\hline Justice & 55 & 7 & - & 19 & 63 & 5 & 149 \\
\hline Freedom & 49 & 54 & & - & 41 & 32 & 289 \\
\hline Nation & 43 & 69 & 28 & 14 & 8 & - & 162 \\
\hline Sovereignty & 35 & - & 29 & 26 & 12 & - & 102 \\
\hline Law & 33 & - & - & - & 41 & 6 & 80 \\
\hline Public & 29 & 30 & - & 11 & - & - & 70 \\
\hline Repuclic & 29 & 17 & 15 & 11 & - & - & 72 \\
\hline Election & 28 & 8 & - & 7 & 12 & 5 & 60 \\
\hline State & 25 & 20 & 17 & 7 & 9 & 12 & 90 \\
\hline Independency & 23 & 61 & - & 98 & 13 & 10 & 205 \\
\hline Atatürk & 16 & 26 & 19 & 19 & 6 & - & 86 \\
\hline Council & 15 & 22 & - & 7 & 5 & - & 49 \\
\hline Governance & 14 & 30 & 5 & - & - & - & 49 \\
\hline TBMM & 13 & 25 & - & - & - & - & 38 \\
\hline Turkey & 13 & - & 21 & 6 & - & - & 40 \\
\hline Voting & 13 & - & - & - & 11 & - & 24 \\
\hline Homeland & 11 & 15 & 14 & - & - & 5 & 45 \\
\hline Elect and be Elected & 11 & - & - & - & 38 & - & 49 \\
\hline Court & 10 & 6 & - & - & 16 & - & 32 \\
\hline Responsibility & 5 & 6 & 15 & 34 & 40 & - & 100 \\
\hline Unity & 5 & 8 & - & - & 9 & - & 22 \\
\hline Democracy & - & 22 & 22 & 18 & 16 & - & 78 \\
\hline 23 April & - & 20 & - & - & - & - & 20 \\
\hline Human & - & 11 & - & 14 & 21 & - & 46 \\
\hline Community & - & 15 & - & - & - & - & 15 \\
\hline Will & - & 9 & 18 & 29 & 5 & 32 & 93 \\
\hline Liberty & - & 6 & 32 & 37 & 5 & - & 80 \\
\hline Judgment & - & 5 & 6 & - & 5 & - & 16 \\
\hline Choose & - & 5 & - & 10 & - & - & 15 \\
\hline Flag & - & 5 & 36 & 6 & - & - & 47 \\
\hline Independence War & - & - & 20 & - & - & - & 20 \\
\hline Permissiveness & - & - & 14 & 30 & - & - & 44 \\
\hline Bird & - & - & 5 & 13 & - & - & 18 \\
\hline Life & - & - & - & 25 & 13 & - & 38 \\
\hline Human Rights & - & - & - & - & 23 & - & 23 \\
\hline Child & - & - & - & - & 16 & - & 16 \\
\hline Task & - & - & - & - & - & 75 & 75 \\
\hline Duty & - & - & - & - & - & 50 & 50 \\
\hline Work & - & - & - & - & - & 50 & 50 \\
\hline Obligation & - & - & - & - & - & 38 & 38 \\
\hline Person & - & - & - & - & - & 23 & 23 \\
\hline Lesson & - & - & - & - & - & 16 & 16 \\
\hline Order & - & - & - & - & - & 27 & 27 \\
\hline School & - & - & - & - & - & 16 & 16 \\
\hline
\end{tabular}

Number of response concepts given to the concepts of democracy, sovereignty, independency, freedom, rights and responsibility is given in the table above. Students participated in the study have associated 6 key concepts in total with 46 response concepts in total. When examining the table, it is seen that students associate sovereignty concept with 27 different concepts, they associate right concept with 24 different concepts. They associate democracy concept with 23 different concepts and associate freedom concept with 23 different concepts. They also associate independency concept with 20 different concepts and associate responsibility concept with 17 different concepts.

When examining Table 1, response concepts mostly associated with key concepts are: democracy key concept is associated with equality (87) response concept, sovereignty key concept is associated with nation (69) response concept, independency key concept is associated with freedom (113) response concept, freedom key concept is associated with independency (98) response concept and responsibility key concept is associated with duty (75) response concept. And when examining the table again, it is seen that a different key concept is given as response concept to some key concepts while the given key concepts are associated with response concepts different from each other. For example, 
key concepts such as sovereignty is associated with the concept as response concepts by the students while democracy key concept is associated with different response concepts such as justice, nation, laws.

In addition, it is another remarkable finding in the table that some of the response concepts given to key concepts are common. Equality response concept can be given as example to independency, right and sovereignty key concepts.

Conceptual networks that are prepared considering frequency table and present cognitive structures of the students are as the following. The emerging concepts can be followed more easily by making every breakpoint with a different color in the conceptual networks. Concepts with breakpoint 76 and above are indicated by black, concepts with breakpoint 61 to 75 are indicated by red, concepts with breakpoint 46 to 60 are indicated by blue, concepts with breakpoint 31 to 45 are indicated by green, concepts with breakpoint 16 to 30 are indicated by yellow and concepts with breakpoint 1 to 16 are indicated by purple.

Results seen in the conceptual network can be interpreted as the following:

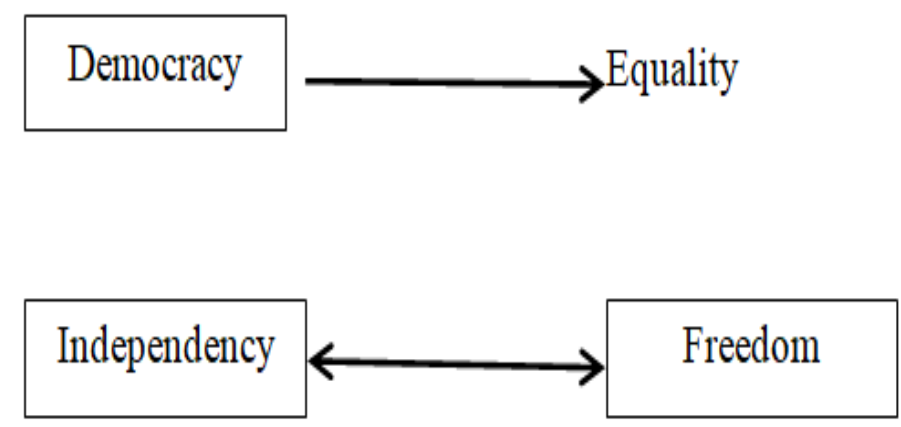

Figure 1. Conceptual network formed by breakpoint 76 and above

When examining conceptual network formed by breakpoint 76 and above, we see that only 2 of 6 the specified key concepts are involved. When examining Figure 1, democracy key concept is imagined as equality concept and independency key concept is imagined as freedom concept by the students. In the map, there is no relationship both between key concepts and between response concepts. For that reason, any cognitive structure hasn't been formed yet.

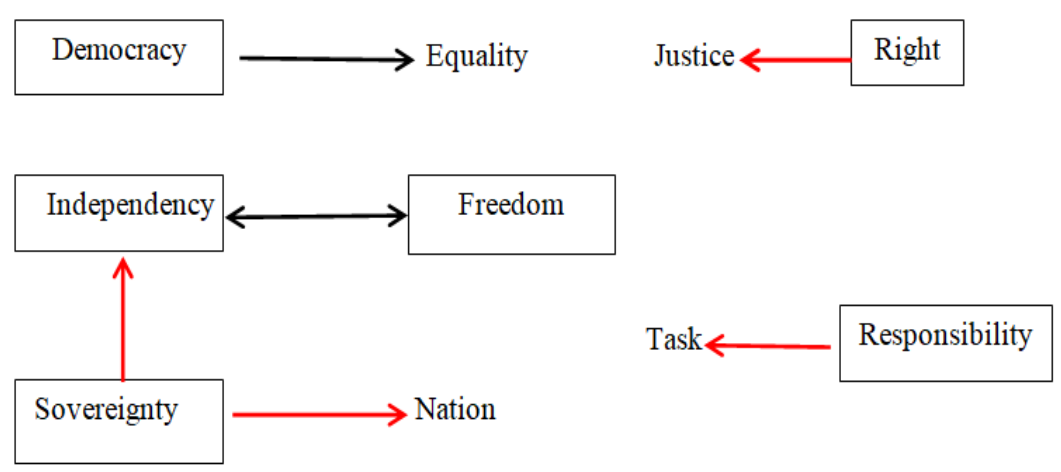

Figure 2. Conceptual network formed by breakpoint 61 to 75

When examining map of conceptual network formed by breakpoint 61 to 75 , it is seen that there is an increase in both amount of key concepts and amount of answer concepts on the map. Besides, there are relationships between the key concepts. For example, sovereignty concept that is another key concept is given as a response concept to independency key concept. In this way, the relation initiated between the concepts on the map demonstrates gradually cognitive structure of the students. When examining the table, in addition to this, democracy, responsibility and right key concepts are involved on the map as squares independent from other key concepts. It is seen that there isn't any relation between these key concepts and other concepts since these key concepts create squares independent from other concepts. 


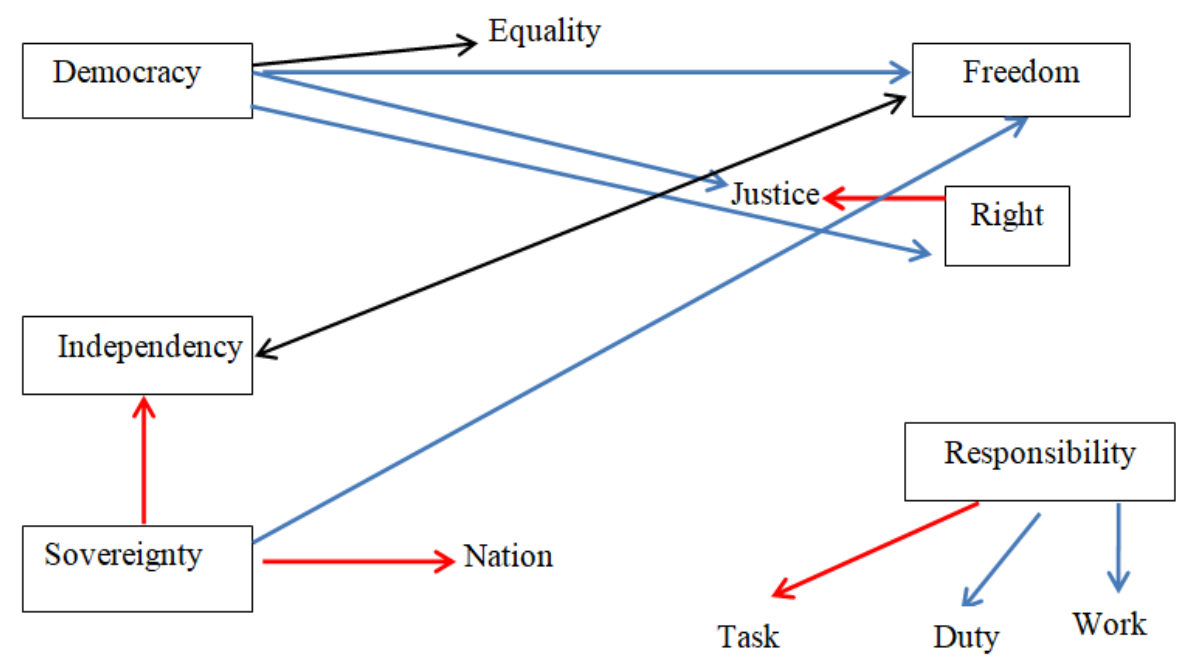

Figure 3. Conceptual network formed by breakpoint 46 to 60

When examining map of conceptual network formed by breakpoint 46 to 60 , it is seen that there is an increase in both amount of key concepts and amount of answer concepts on the map and also in associations between key concepts. For example, democracy is given as response concept to freedom key concept and freedom concept that is another key concept is given as a response concept to sovereignty key concept. And it is seen that a key concept is associated with more than one key concept as response concept on the map. In this way, initiation of the relation between the concepts on the map demonstrates gradually cognitive structure of the students. When examining the table, in addition to this, democracy, responsibility and right key concepts are involved on the map as squares independent from other key concepts. It is seen that there isn't any relation between these key concepts and other concepts yet since they create squares independent from other concepts. It may be an example that democracy, independency and sovereignty key concepts are given as response concepts to freedom concept. Another finding seen on the map is that associated concepts are involved in not only key concepts but also they are involved in response concepts. For example, justice response concept is the answer given to both right key concept and democracy key concept. In this regard, initiation of the relations between the concepts on the map demonstrates cognitive structure of the students in a more obvious way. When examining figure 3 , in addition to this, it is seen that sovereignty key concept is involved on the map as a square independent from other key concepts. This situation shows us that any relation hasn't started between this key concept and other key concepts yet.

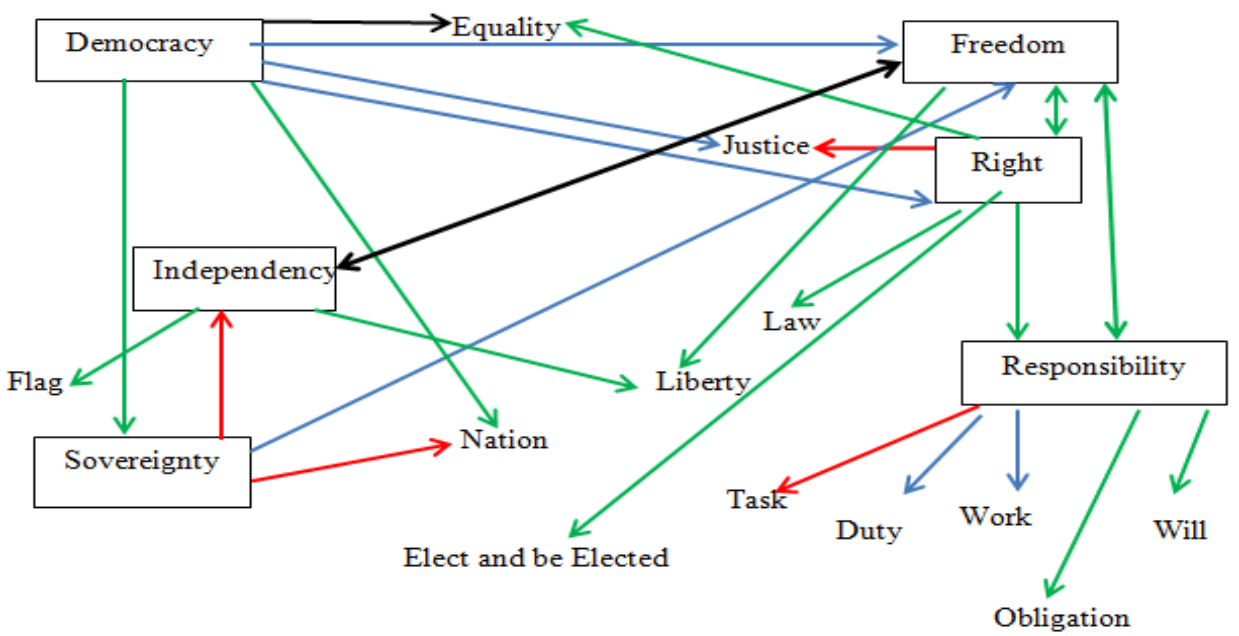

Figure 4. Conceptual network formed by breakpoint 31 to 45

When examining map of conceptual network formed by breakpoint 31 to 45, it is seen that all of the key concepts are involved on the map and there is an increase in response concept in number. Besides, key words continue to be involved on the map as response concepts as well. In addition to this, new relations between the concepts are added to the concept map. For example, liberty is given as response concept to freedom key concept and electing - being elected is given as response concept to right key concept. Again, another remarkable element on conceptual network is the 
relationship between key concepts. When examining the relationship between democracy, independency and sovereignty key concepts, for example, we can say that sovereignty key concept is associated with democracy and independency key concepts but democracy and independency key concepts are not associated with each other.

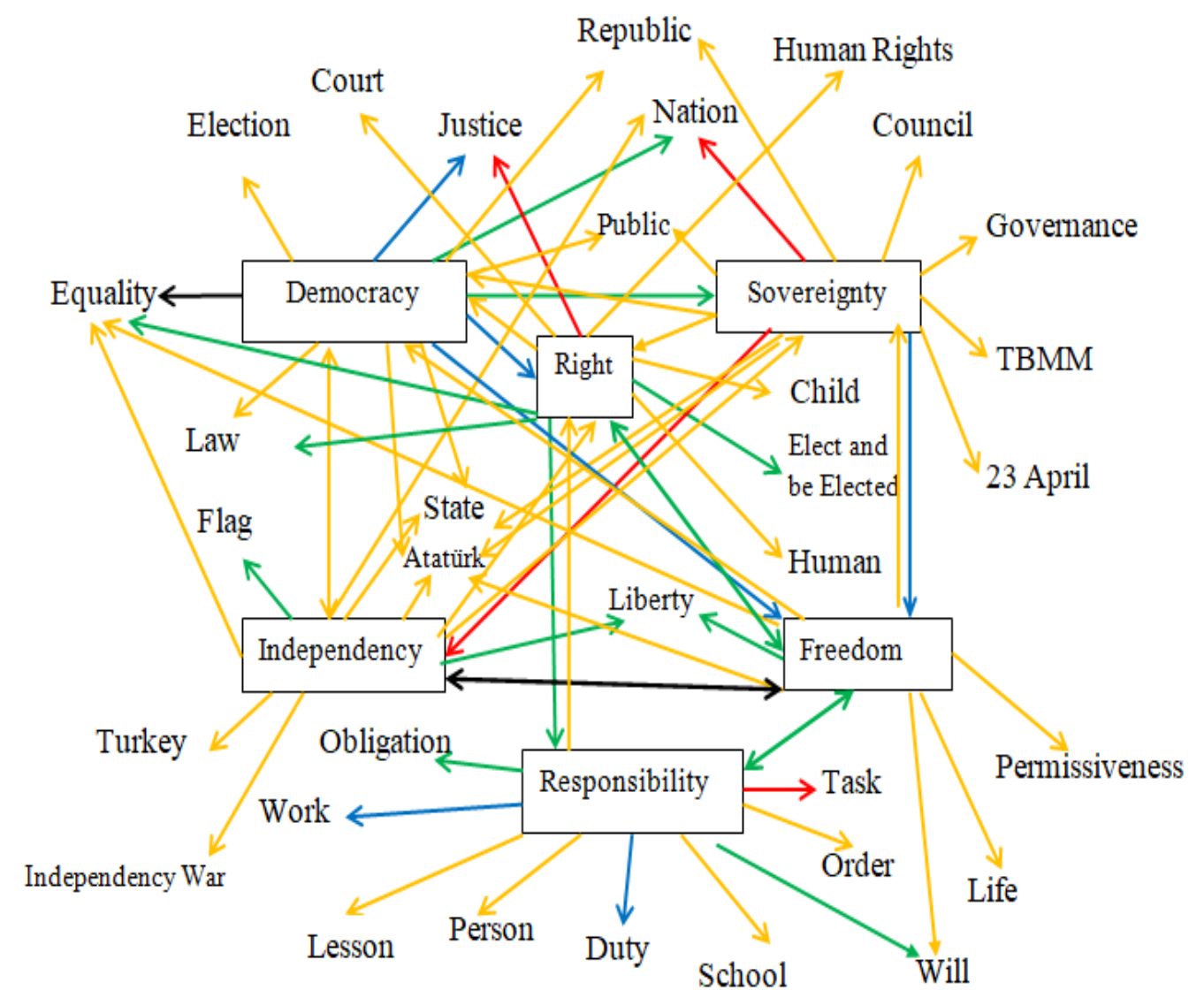

Figure 5. Conceptual network formed by breakpoint 16 to 30

When examining map of conceptual network formed by breakpoint 16 to 30 , it is seen that increase of concepts in number increases also by the amount of other breakpoints. According to the map, an increase is seen in the amount of common response concepts to some key concepts. For example, Ataturk appears as a response concept for key concepts of democracy, independency, freedom and sovereignty. Another considerable element on the map is that response concepts given to the key concepts are excessive in number. Many and various response concepts can be stated as an indicator that these concepts are involved significantly in cognitive structures of the students and they are understood by the students. It shows that at least one of the key concepts presented on the map is response concept (this number can be much more) and thus all of the key concepts are associated with each other. 


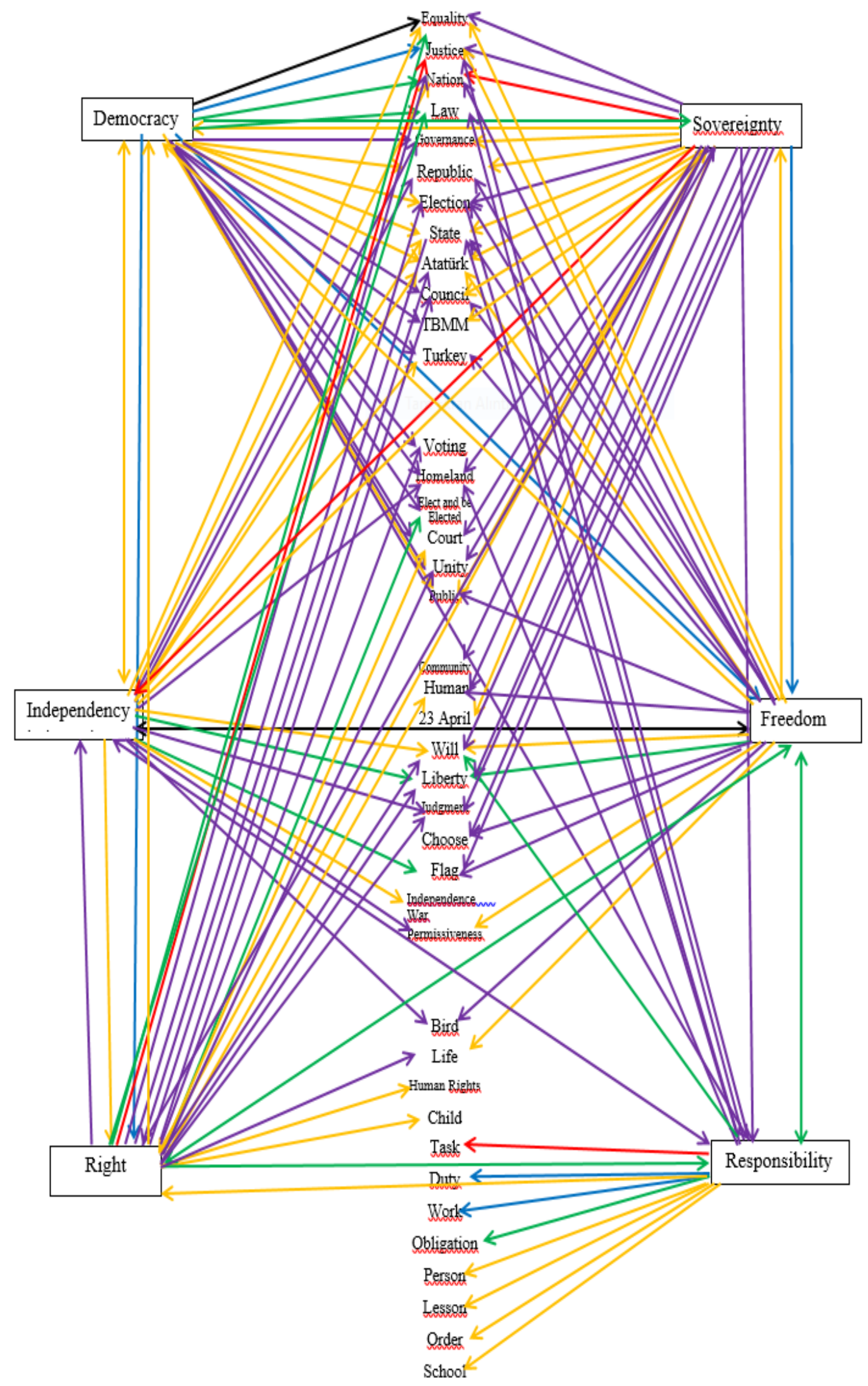

Figure 6. Conceptual network formed by breakpoint 15 and below 
There are all key concepts which are specified previously in the conceptual network map formed by breakpoint 15 and below. In addition to this, an increase is seen in the number of response concepts. According to the map, increase in the number of response concepts given mutually to key concepts is remarkable. For example, students wrote responsibility response concept to democracy and sovereignty key concepts at the same time, and they also wrote unity response concept in reply to democracy, sovereignty and right key words. Another finding seen on conceptual network is that all the key concepts are also associated with each other as response concepts to each other.

Table 2. Frequency table of the sentences formed by the students concerning key concepts

\begin{tabular}{lccccc}
\hline & $\begin{array}{c}\text { Sentence Containing } \\
\text { ScientificInformation }\end{array}$ & $\begin{array}{c}\text { Sentence Without } \\
\text { Scientific Information }\end{array}$ & $\begin{array}{c}\text { SentenceContaining } \\
\text { Misconceptions }\end{array}$ & Empty & Total \\
\hline Democracy & 128 & 20 & 2 & 74 & 25 \\
\hline Sovereignty & 50 & 13 & - & 48 & 175 \\
\hline Independency & 147 & 20 & - & 8 & 175 \\
\hline Freedom & 156 & 11 & - & 175 & 175 \\
\hline Responsibility & 132 & 18 & 10 & 38 & 175 \\
\hline Right & 102 & 25 & 175 \\
\hline
\end{tabular}

Table 2 illustrates the frequencies determined by evaluating sentences in "the relevant sentence" section written by the students concerning key word specified within scope of the study. According to Table 2, it is seen that 128 of 175 students participated in the study formed sentences involving scientific information about democracy concept. 20 is the number of sentences which don't involve scientific information about democracy and which indicate mostly feelings and opinions of the students about key concept. 2 is the number of sentence written by the students which include misconceptions. And 25 students couldn't form any sentence about democracy. To give an example for the sentences formed by students including scientific information: "democracy is the system in which public is ruled by people they elected.", "all the people are equal in democracies regardless of social and economic." As for the students formed sentences not involving scientific information about democracy concept, it can be said that their cognitive structures concerning democracy concept are weak. One of the sentences written in this category is "Democracy is the system by which people would live free and happily on the world."

In the study, sovereignty is another key concept for which students asked to write a relevant sentence. As seen on table 2, when analyzing sentences of the students, it has been determined that only 50 students wrote sentences involving scientific information to this concept and 13 students wrote sentences not involving scientific information and 48 students didn't write any sentence. A major part of the students (74) formed sentences including misconceptions. It can be stated from this findings that students have difficulty in understanding sovereignty concept and have misunderstanding with content of the concept in their minds. "Sovereignty is an independent state" statement can be given as example to a student's sentence including scientific information. To give examples for sentences including misconceptions about sovereignty concept, "Sovereignty is a regime", "It is that people can do anything they want". Most of the students understand sovereignty concept as regime. And it indicates that students have difficulty in learning sovereignty concept. The reason why they have difficulty may be that this concept is an abstract concept and it is not used frequently by the students in daily life.

When examining sentences formed by the students about key concepts of independency, freedom and responsibility, it is seen that most of the students form sentences involving scientific information about these concepts (Independency-147/Freedom-156/Responsibiltiy-132). While we don't observe any sentence of the students involving misconceptions about these two concepts, it is determined that number of the students who left the relevant sentence section empty and formed sentenced not including scientific information is not much. We can say from this finding that comprehension levels of the students about these two concepts are good. Some of the example sentences including scientific information about freedom concept are "to be able to make what you want by obeying the rules", "to be able to make what you want without any restrictions". Some of the example sentences including scientific information about independency are "To live without depending on anybody", "Independency is not being under cover of other countries". When evaluating sentences of the students about independency, it is seen that they evaluated independency concept in terms of both individuals and states. As for the sentences of students including scientific information about responsibility concepts, examples are "an obligation of somebody to do something", "Responsibility is not only towards somebody else; a person has responsibilities towards himself too".

In the study, right is another key concept which students were asked to form relevant sentences. When evaluating the sentences about right concept, it is seen that most of them wrote sentences including scientific information (102); "Laws give us our rights", "Anybody has equal rights in the society". While 25 students wrote sentences not involving scientific information about this concept, 38 students didn't write any sentence. Number of the students wrote sentences involving misconceptions about rights is 10 . It has been determined that a major part of the students have misconceptions confuse this concept with responsibility and freedom concepts. Example sentences of the students in 
this category are "to be able to do whatever we want", "our obligations which we have to fulfill". From this finding, it can be concluded that students have good levels to understand right concept and there are yet a few students who have misconceptions.

\section{Results and Discussion}

In this study, cognitive structures of $8^{\text {th }}$ grade students about democracy, sovereignty, independency, freedom, right and responsibility concepts have been examined. It is concluded when examining cognitive structures of the students about democracy in the study that students associate democracy key concept mostly with the concepts such as equality, right, justice, freedom, nation, sovereignty, laws. These concepts show that they have an important place in mental structures of the students concerning the democracy concept. When examining the literature, Gürbüz (2006), Soydaş (2010), Kaya (2011) determined in their study that students associate democracy concepts mostly with freedom concept. Sadık and Sar1 (2012) determined in their study in which they examined perceptions of the students on democracy that students explain democracy mostly with equality, freedom and justice concepts. As for Karatekin and Elvan (2016), they obtained similar results in the study by which they determined cognitive structures of $8^{\text {th }}$ grade students on democracy concept. In this study, equality, freedom and justice concepts are the first 3 concepts which students associate democracy mostly with. It is one of the most important indicators that students considers democracy as a regime including the concepts they associated with this concept since students associate it, in their minds, with the concepts mentioned in the definition which democracy is defined as a regime that requires mutual tolerance, that is engaged with legal values such as right, freedom, equality, justice and that prioritizes and gives particular importance to human (Çiftçi, 2008, p. 185). However, it is crucial to state that it is determined as a result of the study that students made less associations with concepts such as electing-being elected, council which are important elements of democracy. Democracy has a meaning with all the elements creating itself. Therefore, it is required to bring students in their responsibilities towards democracy in this regard such as democratic values.

Another result obtained in the study is that cognitive structures of students concerning sovereignty concept. Another result obtained in the study is that cognitive structures of students concerning sovereignty concept. When examining conceptual networks of sovereignty concept defined as a power which doesn't recognize any other power and a political and legal organization owned by the state (Evirgen, Özkan, Öztürk and Özdural, 2017, p.190), it is seen that students associate sovereignty concept with freedom, nation and independency concepts. It can be concluded from this point that students could make proper associations with the concept. Yilmaz (2013) stated in his study that students associate sovereignty concepts especially with right and independency concepts.

When examining cognitive structures of the students about independency concept defined as a status and qualification of independency, it is determined that students associate this concept mostly with freedom concept. It is followed by flag and liberty concepts, respectively. And it shows that independency concept is involved in cognitive structures of the students with freedom and liberty concepts which can be stated as synonyms. Again, the reason why students associate independency concept with flag concept may be that flag concept is repeated very frequently as a symbol of independency both in daily life and classes and it is involved in their mental structures in this way. Kaya (2011) found in his study which have parallels with these results that freedom concept is one of the words which students associate with independency concept mostly.

When evaluating data obtained as a result of the study, the following results have been obtained concerning cognitive structures of the students about freedom and responsibility concepts. A good part of the students associated independency with freedom concept. We can say the reason is that these two concepts have the same meanings, in other words, this kind of association is made by minds of the students between two concepts as a consequence. When examining cognitive structures of the students about responsibility concept, it is concluded that students associate this concept mostly with task, duty and work concepts, respectively. When examining these concepts associated with responsibility concept which is defined as that child fulfils his duties in accordance with the age, gender and development level from the childhood (Yavuzer, 1998, p. 107), the reason for this situation may be that both parents and teachers at schools use responsibility concept especially together with duty concept. Besides, it can be concluded that there is a relationship between responsibility and duty (Kuş, 2012, p.26) and it can be adopted by students as well. Just as the result of this study, Kartal and Turan (2015) found that students associate responsibility concept mostly with duty concept.

As a result of the study carried out on right concept which means benefits granted to the people and protected by a legal order and left to self control of the individual to use it (Bozkurt, 2011, p. 243), it has been determined that students associate right concept with concepts of justice, freedom, law and responsibility. Right concept is also a legal term and when we consider that subject of the right is living and behavior areas not only belonging to an individual but also other people, it is indicated that students consider these features since they associate it with concepts such as freedom, justice in their mental structures. 
In this study, cognitive structures of the secondary school students concerning the basic citizenship concepts within the scope of social sciences lesson have been determined and also their sentences on these concepts have been evaluated. Sentences were evaluated in the categories of sentences involving scientific information about the specified concepts, sentences not involving scientific information, sentences involving misconceptions and empty sentences, and it was thus tried to demonstrate place of these concepts in cognitive structures of the students better.

As a result of the analysis on the sentences formed by students concerning democracy, sovereignty, independency, freedom, right and responsibility concepts, it has been determined that while students can form sentences involving scientific information about certain concepts, they also have misconceptions about certain concepts. Individuals are required to be raised with this awareness as of the childhood and they should know what the democracy is; democracy can be thus turned into a life style. Schools are the most important institutions to do it. The better democracy is transferred within the education system, the more individuals with this awareness will increase. When evaluating results of the analysis, it has been seen that most of the students formed sentences involving scientific information about democracy concept. And it shows us that students create democracy concept in their cognitive structures properly. Besides, it has been determined that there are a few students have misconceptions about democracy concept. This finding conforms to result of the study carried out by Karatekin and Elvan (2016). In the study carried out with $8^{\text {th }}$ grade students, they found that students have no misconceptions about democracy concept.

When analyzing sentences of the students about sovereignty concept, some of the results obtained by the study are that many students have misconceptions about this concept; there are a limited number of students who formed sentences involving scientific information; besides, there are many students who couldn't write any sentence. Students define sovereignty concepts especially as a regime or a self-governance by the people. In addition, students who defined sovereignty as freedom were determined as a result of the study. The reason why students have misconceptions about sovereignty may be that it is an abstract concept and students have difficulties in understanding the concepts which they don't often encounter and experience in daily life. When examining the studies carried out on sovereignty concept, it is seen that misconceptions have been determined with the students (Kaya, 2011; Yılmaz, 2013; Pala, 2018). Again, Memişoğlu and Tarhan (2016) stated in their study for which they asked opinions of social sciences teachers about concept teaching that sovereignty is one of the concepts which students have misconceptions mostly

Another result obtained from the study is that a good part of the students can form sentences including scientific information about independency, responsibility and freedom concepts and have no misconceptions about these concepts. In addition, there is a limited number of the students who can't form sentences about these concepts. These results show us that cognitive structures of the students on these three concepts are created properly. These results of the study show parallelism with studies by Kaya (2011) and Yllmaz (2013). Kaya (2011) found in his study in which he determined levels of the primary school students to understand some democracy concepts that answers given by the students about independency concept can explain this concept completely and students have no misconceptions about this concept. Yllmaz (2013) determined in his study that most students participated in the study have no misconception about responsibility concept and they defined responsibility concept correctly. Yllmaz (2013), who stated that students have no difficulty in defining this concept since it is a course of action they experienced personally the responsibility concept as of the young ages in their families and social lives, stated that students may have understood this concept better since this concept is included very frequently in curriculum of citizenship and human rights.

When evaluating sentences of the students concerning right concept, it is concluded that students can form sentences involving scientific information about this concept and there a few students who have misconceptions about this concept. This result indicates that students have sufficient information about right concept. In addition, when examining sentences formed by the students, it is seen that they define right concept both in individual and social sense.

As seen as a result of this study, a considerable part of the students created their cognitive structures associated with citizenship concepts in a proper manner and also they can explain most of the concepts scientifically. Moreover, it should be noted that there are some concepts on which students have misconceptions. Since most of the concepts about citizenship are abstract, concepts should be associated with daily life properly especially when teaching these concepts. Thus, these concepts would not remain as abstract words in their cognitive structures and it will be easier to learn when they encounter these concepts in their lives.

\section{References}

Bahar, M., \& Özatl1, N. S. (2003). Investigation of cognitive structures of high school students about the basic components of living things by word communication test method. Journal of Ballkesir University Institute Science and Technology, 5(2), 75-85.

Bahar, M., Johnstone, A. H., \& Sutcliffe, R. G. (1999). Investigation of students' cognitive structure in elementary genetics through word association tests. Journal of Biological Education, 33, 134-141. 
Bolat, A., Aydoğdu, R. Ü., \& Sağır, U. Ş. (2014). 5th grade students' misconceptions related to the subjects of "the sun, the earth and the moon". Journal of Research in Education and Teaching, 3(1), 218-229.

Bozkurt, E. (2011). Genel hukuk bilgisi. Ankara: Yetkin Publications.

Çepni, S., Özmen, H., \& Bakırcı, H. (2012). Developing instructional material appropriate to the common knowledge construction model: "the interaction of light with matter and its reflection example". X. National Science and Mathematics Education Congress, Niğde.

Çiftçi, A. (2008). Vatandaşlık bilgisi- demokrasi ve insan haklarl (2nd ed.). Ankara: Gündüz Education and Publishing.

Doğanay, A. (2005). Sosyal bilgiler öğretimi. C. Öztürk \& D. Dilek (Ed.). Hayat bilgisi ve sosyal bilgiler ögrretimi (5th ed.). Ankara: Pegem A.

Evirgen, Ö. F., Özkan, J., Öztürk, S., \& Özdural, Z. (2017). Ortaokul sosyal bilgiler ders kitabı 5. A. Altun, S. Elmacı \& A. Beldağ (Ed.). İstanbul: Bilnet

Gürbüz, G. (2006). Democracy education of the elementary school at 7th and 8th classes at citizenship lesson. (Unpublished master thesis). Abant İzzet Baysal University, Bolu, Turkey.

Kaldırım, E. (2005). Democracy perceptions of eight grade students. Journal of Gazi University Gazi Education Faculty, 25(3), 143-162.

Karatekin, K., \& Elvan, Ö. (2016). The cognitive schema of 8th grade students about democracy. Journal of Abant İzzet Baysal University Education Faculty, 16(USBES Special Issue II), 1405-1431.

Kartal, A., \& Turan, İ. (2015). The misconceptions about citizenship in 5th grade students' mind maps. The Journal of Academic Social Science Studies, 34, 373-383.

Kaya, E. (2011). Some views on democracy and the collapse of concepts of elementary school students 7th class (Aksaray case) (Unpublished master thesis). Niğde University, Aksaray, Turkey.

Kuş, Z. (2012). Exploring of middle school students? democracy perceptions according to different variables (Unpublished doctoral thesis). Gazi University, Ankara, Turkey.

MEB (2005). Primary social studies lesson 6-7. classes curriculum and guide (draft edition). Ankara: Directorate of State Books.

Memişoğlu, H., \& Tarhan, E. (2016). Opinions of social studies teachers about concept teaching. Journal of Research in Education and Teaching, 5(2), Special Issue, 6-20.

Özatlı, N. S., \& Bahar, M. (2010). Revealing students' cognitive structures regarding excretory system by new techniques. Journal of Abant İzet Baysal University, 10(2), 9-26.

Pala, F. (2018). 7th grade social sciences concepts of the living democracy unit level of understanding. Journal of Turkey Education, 3(1), 22-36.

Sadık, F., \& Sarı, M. (2012). Child and democracy: examination of elementary education school students' democracy perception by metaphors. Cumhuriyet International Journal of Education, 1(1), 48-62.

Safran, M. (2011). Sosyal bilgiler öğretimine bakış. B. Tay \& A. Öcal (Ed.). Özel öğretim yöntemleriyle sosyal bilgiler ögretimi (2nd ed.). Ankara: Pegem Akademi.

Soydaş, S. (2010). The research of the metaphores, related with the democracy and democratic life, created by the students that were gained in the social studies lesson (Unpublished master thesis). Çanakkale Onsekiz Mart University, Çanakkale, Turkey.

Yavuzer, H. (1998). Çocuk eğitimi el kitabı., İstanbul: Remzi Bookstore.

Y1lmaz, K. (2013). An investigation into elementary school students' perceptions of basic concepts about citizenship education. Hacettepe University Journal of Education, 28(1), 453-463.

\section{Copyrights}

Copyright for this article is retained by the author(s), with first publication rights granted to the journal.

This is an open-access article distributed under the terms and conditions of the Creative Commons Attribution license which permits unrestricted use, distribution, and reproduction in any medium, provided the original work is properly cited. 